\title{
Faktor-faktor yang mempengaruhi ketahanan pangan rumah tangga di Kota Medan
}

\author{
Factors that affected household food security in Medan city
}

\author{
Nathasa Weisdania Sihite ${ }^{1}$, Ikeu Tanziha²
}

\author{
1 Jurusan Gizi Politeknik Kesehatan \\ Kemenkes Palembang. Indonesia. \\ E-mail: weisdania@gmail.com \\ 2 Departemen Gizi Masyarakat, Fakultas \\ Ekologi Manusia, Institut Pertanian \\ Bogor. Indonesia. \\ E-mail: ikeutanziha@gmail.com
}

\section{*Korespondensi:}

Jurusan Gizi Politeknik Kesehatan Kemenkes Palembang, Jln. Sukabangun 1 No. 2632. Palembang, Indonesia.

E-mail:weisdania@gmail.com

\section{Riwayat Artikel:}

Diterima tanggal 25 Agustus 2020; Direvisi tanggal 11 September 2020; Disetujui tanggal 14 September 2020; Dipublikasi tanggal 26 Mei 2021

\section{Penerbit:}

Politeknik Kesehatan Aceh Kementerian Kesehatan R

\section{(c) The Author(s). 2021 Open Access} Artikel ini telah
dilakukan distribusi dilakukan distribusi
berdasarkan atas ketentuan Lisensi Internasional Creative Commons Attribution 4.0

\begin{abstract}
Sufficient food availability in an area does not guarantee household food security. Household food security is a condition for the fulfillment of food for every household both in terms of quantity and quality. The purpose of this research was to determine the factors related to household food security in Medan City. The research design used was a cross-sectional design. The location was in Medan Kota and Medan Denai District that chosen purposively with criteria for poverty level is $15-20$ percent. The household sample was taken randomly as 120 households with the criteria prosperity (Pra KS and KS 1,2,3). The result of the research shows that $67,5 \%$ of households were household food insecurity, and $32,5 \%$ of households were household food security. Household expenditure has a relationship with household food security $(p=0,000)$, while the age of the household head, number of family members, and education level did not show any relationship $(p>0,05)$. In conclusion, that household expenditure has a direct effect on the status of household food security in Medan City. There needs to be a strategy and active participation from the local government in overcoming the problem of household food security in Medan City.
\end{abstract}

Keywords: Food insecurity, food security, household

\section{Abstrak}

Ketersediaan pangan yang memadai di suatu wilayah tidak menjamin ketahanan pangan di tingkat rumah tangga. Ketahanan pangan (Food Security) rumah tangga merupakan suatu kondisi terpenuhinya pangan bagi setiap rumah tangga baik dari aspek kuantitas maupun aspek kualitas. Tujuan penelitian untuk mengukur faktor-faktor yang berhubungan dengan ketahanan pangan rumah tangga di Kota Medan. Desain penelitian yang digunakan adalah Cross Sectional Study. Penelitian dilakukan di Kecamatan Medan Kota dan Kecamatan Medan Denai, Provinsi Sumatera Utara. Tempat penelitian ditentukan secara purposive berdasarkan tingkat kemiskinan sedang $15-20 \%$. Sampel rumah tangga diambil secara acak sebanyak 120 rumah tangga yang meliputi Pra KS (Keluarga Sejahtera) dan KS (Keluarga Sejahtera) 1, 2, 3. Data hasil penelitian dianalisis dengan uji korelasi Pearson, Rank Spearman dan analisis regresi. Hasil penelitian menunjukkan mayoritas rumah tangga mengalami rawan pangan yaitu $67,5 \%$ dan rumah tangga yang tahan pangan $32,5 \%$. Pengeluaran rumah tangga memiliki hubungan dengan ketahanan pangan rumah tangga $(p=0,000)$, sedangkan umur KRT, jumlah anggota keluarga, dan tingkat Pendidikan tidak menunjukkan hubungan ( $p$ > 0,05 ). Kesimpulan, pengeluaran rumah tangga memberi pengaruh secara langsung terhadap status ketahanan pangan rumah tangga di Kota Medan. Saran, perlu strategi dan partisipasi aktif dari pemerintah setempat dalam menanggulangi masalah ketahanan pangan rumah tangga di Kota Medan.

Kata Kunci: Ketahanan pangan, kerawanan pangan, rumah tangga 


\section{Pendahuluan}

Secara global kerawanan pangan (Food Insecurity) masih menjadi masalah utama yang banyak terjadi di negara-negara di dunia baik dalam negara yang sedang berkembang maupun negara maju (Conceição et al., 2016). Setiap provinsi di Indonesia memiliki keragaman ekosistem yang khas, dan biasanya keragaman ekosistem provinsi yang satu berbeda dengan provinsi lain. Keragaman ekosistem juga berkaitan dengan jumlah penduduk suatu provinsi, dimana suatu provinsi harus dapat memenuhi kebutuhan pangan penduduk baik itu di level rumah tangga maupun perorangan.

Pangan merupakan hak asasi mendasar yang dibutuhkan oleh setiap orang didunia, tidak memandang jenis kelamin pria atau wanita, pemenuhan pangan harus tercukupi dan menjadi hal yang sangat mendasar bagi pembangunan suatu negara. Hal inilah yang membuat ketahanan pangan menjadi suatu fondasi yang sangat penting dalam pembangunan (Musindar \& Arhim, 2018). Mekonnen \& Gerber (2017) berpendapat bahwa "ketahanan pangan dan kemiskinan masih menjadi masalah utama sekaligus tantangan dalam pembangunan suatu negara" berdasarkan hal tersebut, dapat diketahui bahwa ketahanan pangan menjadi salah satu syarat dalam pembangunan suatu wilayah yang dapat dilihat dari beberapa aspek penting seperti, peningkatan produksi pangan, akses distribusi pangan yang cepat diakses, serta ketersediaan konsumsi pangan yang aman dan bergizi bagi seluruh lapisan masyarakat (Emy, 2012).

Hasil analisis Pola Pangan Harapan (PPH) di Kota Medan Tahun 2012 menunjukkan skor PPH lapisan masyarakat Kota Medan memiliki indeks berkisar 87,0; dengan indeks konsumsi energi sebesar 2.071 kkal perkapita/hari serta konsumsi protein berkisar 61,06 gram perkapita/hari. Kota medan mengalami peningkatan skor PPH pada tahun 2016 yaitu sebesar 92,73 dan tahun 2017 sebesar 92,55 (BNP2TKI, 2019). Dengan semakin meningkatnya skor PPH, harusnya masyarakat di Kota Medan dapat mengimbangi gizi dan protein dengan meningkatkan konsumsi pangan lain selain beras. Berdasarkan hal tersebut, demi mengetahui status ketahanan pangan rumah tangga yang berada di Kota Medan diperlukan berbagai jenis data seperti data konsumsi pangan rumah tangga dan data sosial ekonomi rumah tangga yang akan dilihat hubungannya dengan status ketahanan pangan rumah tangga di Kota Medan.

Level ketahanan rumh tangga dapat dipengaruhi oleh berbagai macam faktor baik yang berasal dari rumah tangga itu sendiri maupun faktor yang berasal dari luar rumah tangga. Berdasarkan hasil penelitian yang dilakukan oleh Tanziha (2011), menyebutkan bahwa faktor kemiskinan merupakan penyebab utama yang menyebabkan rumah tangga tergolong dalam rumah tangga yang tidak tahan pangan, adapun faktor lain yang menyebabkan rumah tangga termasuk dalam zona tidak tahan pangan diantaranya adalah masih kurangnya kepedulian masyarakat tentang masalah ketahanan pangan, serta minimnya suatu lembaga ketahanan pangan yang berada di lapisan masyarakat. Masalah lain yang didapatkan dalam penelitian tersebut adalah masih banyaknya persentase rumah tangga yang mengalami kekurangan pangan dan kelaparan yaitu berkisar 43\% (Sumardilah \& Rahmadi, 2015). Data-data yang diduga merupakan faktor-faktor yang dapat mempengaruhi tingkat ketahanan pangan rumah tangga seperti data umur kepala rumah tangga, ukuran rumah tangga, tingkat pendidikan kepala rumah tangga dan pengeluaran rumah akan dijadikan acuan dan sumber informasi dalam menganalisis faktor determinan ketahanan pangan rumah tangga di Kota Medan.

Data tersebut akan dijadikan sebagai sumber utama dalam melakukan analisis penelitian ketahanan pangan rumah tangga di Kota Medan dan diharapkan penelitian ini dapat memberikan pengetahuan dan sumber informasi untuk mengetahui faktor-faktor yang dapat mempengaruhi tingkat ketahanan rumah tangga di Kota Medan.

\section{Metode}

Desain penelitian yang digunakan dalam penelitian ini adalah desain Cross Sectional Study. Lokasi Penelitian dilakukan di Kecamatan Medan Kota dan Medan Denai, Provinsi Sumatera Utara. Tempat penelitian ditentukan secara purposive berdasarkan tingkat kemiskinan sedang 15-20\% dimana masing-maisng kecamatan diwakili dari satu kelurahan. Pemilihan Kelurahan juga didasarkan atas tingkat kemiskinan yang sama dengan Kecamatan, dengan alasan mewakili Kecamatan terpilih. 
Populasi dalam penelitian ini adalah seluruh rumah tangga yang ada di Kota Medan. Penentuan sampel dipilih secara stratified random sampling dengan jumlah masing-masing kategori proporsional sehingga diperoleh sampel sebanyak 120 rumah tangga yang meliputi Pra KS (Keluarga Sejahtera) dan KS (Keluarga Sejahtera) $1,2,3$. Adapun yang menjadi responden penelitian ini adalah kepala rumah tangga, ibu, anak, nenek atau kakek. Data karakteristik rumah tangga meliputi: umur, ukuran rumah tangga, tingkat pendidikan dan pengeluaran rumah tangga dikumpulkan dengan metode wawancara terstruktur yaitu dengan kuesioner.

Data konsumsi pangan dikumpulkan melalui wawancara langsung dengan menggunakan metode kuesioner SQFF (Semi Quantitative Food Frequency). Data yang telah didapatkan kemudian dianalisis secara deskriptif dan statistik. Analisis data dilakukan secara univariat dan bivariat. Analisis bivariat dilakukan untuk melihat sebaran distribusi frekuensi variabel penelitian yang akan dianalisis, sedangkan analisis bivariat diapakai untuk mengetahui hubungan-hubungan antar variabel penelitian yang dianalisis menggunakan analisis korelasi Pearson dan Rank Spearman, sedangkan untuk mengetahui faktor-faktor yang mempengaruhi ketahanan pangan rumah tangga di Kota Medan dianalisis menggunakan uji regresi linier berganda (Multiple Linier Regression).

Penelitian ini telah mendapat persetujuan dari Komisi Etik Institut Pertanian Bogor, pada tanggal 3 Januari 2017, dengan nomor SK Rektor IPB Nomor 6/IT3/PN/2017.

\section{Hasil dan Pembahasan}

Karakteristik rumah tangga mencakup keadaan umum yang terjadi di rumah tangga meliputi data keluarga, data sosio ekonomi dan status dari rumah tangga tersebut. Untuk penelitian ini, karakteristik rumah tangga yang diukur adalah meliputi umur kepala rumah, ukuran rumah tangga, pendidikan kepala rumah tangga dan pengeluaran rumah tangga.

Table 1. Karakteristik rumah tangga sampel berdasarkan umur kepala rumah tangga

\begin{tabular}{|c|c|c|c|c|c|c|}
\hline \multirow[t]{2}{*}{$\begin{array}{c}\text { Karakteristik Kepala Rumah } \\
\text { Tangga (KRT) }\end{array}$} & \multicolumn{2}{|c|}{ Medan Kota $(n=60)$} & \multicolumn{2}{|c|}{$\begin{array}{l}\text { Medan Denai }(\mathrm{n}= \\
60)\end{array}$} & \multicolumn{2}{|c|}{ Total } \\
\hline & $\mathrm{n}$ & $\%$ & $\mathrm{n}$ & $\%$ & $\mathrm{n}$ & $\%$ \\
\hline \multicolumn{7}{|l|}{ Umur } \\
\hline 18-39 tahun (awal) & 20 & 33,3 & 26 & 43,3 & 46 & 38,3 \\
\hline 40-59 tahun (madya) & 32 & 53,3 & 31 & 51,7 & 63 & 52,5 \\
\hline$\geq 60$ tahun (lansia) & 8 & 13,3 & 3 & 5,0 & 11 & 9,2 \\
\hline Rata-rata \pm SD (tahun) & \multicolumn{2}{|c|}{$44,1 \pm 11,8$} & \multicolumn{2}{|c|}{$41,6 \pm 10,9$} & \multicolumn{2}{|c|}{$42,8 \pm 11,4$} \\
\hline \multicolumn{7}{|l|}{ Ukuran Rumah Tangga } \\
\hline$>4$ orang (RT besar) & 48 & 80,0 & 50 & 83,3 & 98 & 81,7 \\
\hline$\leq 4$ orang $($ RT kecil) & 12 & 20,0 & 10 & 16,7 & 22 & 18,3 \\
\hline Rata-rata \pm SD (orang) & \multicolumn{2}{|c|}{$5,1 \pm 1,9$} & \multicolumn{2}{|c|}{$5,4 \pm 2,1$} & \multicolumn{2}{|c|}{$5,2 \pm 2,02$} \\
\hline \multicolumn{7}{|l|}{ Pendidikan } \\
\hline Tidak Sekolah & 6 & 10,0 & 0 & 0,0 & 6 & 5,0 \\
\hline SD & 28 & 46,7 & 27 & 45,0 & 55 & 45,8 \\
\hline SMP & 11 & 18,3 & 12 & 20,0 & 23 & 19,2 \\
\hline SMA & 12 & 20,0 & 21 & 35,0 & 33 & 27,5 \\
\hline PT & 3 & 5,0 & 0 & 0,0 & 3 & 2,5 \\
\hline \multicolumn{7}{|l|}{ Pengeluaran /kapita /bulan } \\
\hline Dibawah GK: <Rp. 234.712, & 34 & 56,7 & 36 & 60,0 & 70 & 58,3 \\
\hline Diatas GK: $\geq$ Rp. 234.712, & 26 & 43,3 & 24 & 40,0 & 50 & 41,7 \\
\hline Rata-rata \pm SD (rupiah) & \multicolumn{2}{|c|}{$233.281+142.295$} & \multicolumn{2}{|c|}{$232.972+131.437$} & \multicolumn{2}{|c|}{$233.126+136.397$} \\
\hline
\end{tabular}

\section{Umur KRT}

Berdasarkan table 1, terlihat bahwa bahwa data karakteristik umur kepala rumah tangga sampel di dua kecamatan berkisar diumur 21-75 tahun.
Persentase terbesar umur kepala rumah tangga masih didalam zona usia produktif, dan masih memungkinkan untuk bekerja secara maksimal, persentase umur sampel penelitian ini 
sesuai dengan rata-rata kelompok umur terbesar di kota medan yaitu 15-64 tahun (Biro Pusat Statistik, 2018). Umur merupakan faktor penting dalam menentukan keputusan di suatu keluarga/rumah tangga, kebijakan pengambilan keputusan sering ditentukan oleh tingkat kedewasaan seseorang dalam berperilaku kepada setiap anggota rumah tanngganya. Umur juga menentukan bagaimana tingkat produktifitas seseorang dalam bekerja maupun berusaha.

\section{Ukuran Rumah Tangga}

Selanjutya karakteristik ukuran rumah tangga atau lebih dikenal dengan jumlah anggota rumah tangga merupakan banyaknya orang yang tinggal dalam satu rumah dan masih menjadi tanggung jawab dari seorang kepala rumah tangga.

Hasil penelitian menunjukkan bahwa mayoritas ukuran rumah tangga sampel termasuk dalam rumah tangga besar $(81,7 \%)$ atau berjumlah lebih dari 4 orang dalam satu rumah tangga, jika jumlah ukuran rumah tangga semakin besar hal ini akan berakibat dalam meningkatkan jumlah tanggungan dari rumah tangga tersebut, pada akhirnya kebutuhan biaya hidup juga akan meningkat seiring meningkatnya jumlah ukuran rumah tangga. Menurut Damayanti \& Khoirudin (2016) yang menyatakan bahwa dengan semakin banyaknya jumlah anggota keluarga dalam rumah tangga akan memberikan efek negatif bagi rumah tangga tersebut, salah satunya adalah dapat menurunkan ketahanan pangan rumah tangga, karena dengan semakin banyaknya jumlah anggota keluarga semakin bertambah juga beban keluarga dalam memenuhi kebutuhan keluarga dalam hal ini termasuk juga kebutuhan pangan.

Selain itu ukuran rumah tanggga yang besar pada sampel penelitian ini juga dipengaruhi oleh luas ukuran rumah tangga, yang dikenal dengan kategori rumah tangga Extended Family. Extended family merupakan rumah tangga yang luas, yang anggota rumah tangganya tidak hanya berisikan ibu, ayah dan anak, akan tetapi juga termasuk anggota rumah tangga yang lain seperti nenek, kakek, cucu, sepupu dan keponakan (Kamoo et al., 2017)

\section{Pendidikan}

Pendidikan kepala rumah tangga sampel dikategorikan berdasarkan lamanya pendidikan (lama sekolah) yang ditempuh oleh kepala rumah tangga. Data karakteristik rumah tangga sampel berdasarkan pendidikan kepala rumah tangga dapat dilihat pada Tabel 1.

Hasil penelitian (Tabel 1), memberikan informasi bahwa mayoritas pendidikan yang ditempuh oleh kepala rumah tangga sampel adalah pendidikan Sekolah Dasar (SD) dengan persentase $45,8 \%$. Dengan tingkat pendidikan yang rendah, kesempatan untuk mencari pekerjaan yang baik akan lebih kecil jika dibandingkan dengan latar belakang pendidikan yang tinggi, berdasarkan masalah tersebut juga akan berdampak negatif terhadap pendapatan yang akan diperoleh oleh rumah tangga sampel penelitian ini. Hal ini sesuai dengan penelitian yang dilakukan oleh Susanti et al. (2015), dimana dijelaskan bahwa tingkat pendidikan erat hubunggannya dengan perekonomian, dimana tingkat pendidikan merupakan salah satu faktor yang menentukan suatu pengambilan keputusan secara tepat yang dipengaruhi oleh pengetahuan sehingga dapat berguna dalam kelangsungan hidup khususnya dalam bidang perekonomian masyarakat.

\section{Pengeluaran Rumah Tangga}

Pengeluaran perkapita perbulan rumah tangga sampel merupakan pengeluaran yang dikeluarkan oleh rumah tangga sampel dalam waktu satu bulan, termasuk untuk kebutuhan pangan maupun non pangan. Pengeluaran rumah tangga juga termasuk seluruh pengeluaran anggota rumah tangga yang dikeluarkan termasuk ayah, ibu, kakek, nenek, sepupu, keponakan dan lain-lain.

Pengeluaran perkapita merupakan hasil konversi pengeluaran rumah tangga yang dikeluarkan selama harian, mingguan, tahunan ke dalam satuan bulan, kemudian dibagi dengan jumlah anggota rumah tangga. BPS pada tahun 2019 telah menetapkan indikator garis kemiskinan (GK) di Kota Medan adalah Rp.234.712 perkapita perbulan (BPS, 2019).

Hasil penelitian menunjukkan bahwa mayoritas rumah tangga sampel tergolong dalam kriteria dibawah garis kemiskinan (GK) yaitu dengan persentase berkisar 58,3\%, sampel memiliki pengeluaran perkapita perbulan < Rp. 234.712,- dengan rata-rata pengeluaran sebesar Rp. 233.126,- perkapita perbulan. Jika melihat antara kedua kecamatan, terlihat bahwa keduanya memiliki pengeluaran rumah tangga yang tergolong dibawah garis kemiskinan (GK). Banyak faktor yang dapat menimbulkan kemiskinan pada rumah tangga sampel, baik pendidikan, jumlah anggota keluarga dan tingkat pendapatan, untuk itu 
akan dilakukan analisis hubungan pengaruh dari variabel-variabel penelitian yang dapat mempengaruhi tingkat ketahanan pangan rumah tangga di Kota Medan.

\section{Ketahanan Pangan Rumah Tangga}

Ketahanan pangan rumah tangga merupakan dasar dari suatu pembangunan wilayah, ketahanan pangan rumah tangga juga berhubungan langsung dengan status gizi masyarakat di suatu wilayah setempat. Terdapat hubungan searah antara status gizi dengan ketahanan pangan, dimana jika ketahanan pangan mengalami kekurangan otomatis akan berdampak dengan kurangnya asupan gizi seseorang, sehingga dapat menyebabkan rendahnya status kesehatan masyarakat setempat. Dengan demikian maka ketahanan pangan sangat erat kaitannya dengan gizi dan kesehatan. Hasil penelitian Arlius yang dilakukan pada tahun 2017 menyebutkan bahwa terdapat hubungan positif diantara tingkat konsumsi energi dan protein balita dengan tingkat ketahanan pangan di rumah tangga (Arlius, 2017). Hasil analisis Tingkat Kecukupan Gizi (TKG) pada penelitian ini dapat dilihat pada Tabel 2 dibawah ini menunjukkan tingkat kecukupan energi dan protein pada rumah tangga sampel.

Tabel 2. Tingkat kecukupan energi dan protein rumah tangga

\begin{tabular}{|c|c|c|c|c|}
\hline \multirow{3}{*}{ Tingkat Kecukupan Gizi } & \multicolumn{4}{|c|}{ Zat Gizi } \\
\hline & \multicolumn{2}{|c|}{ Energi } & \multicolumn{2}{|c|}{ Protein } \\
\hline & $\mathrm{n}$ & $\%$ & $\mathrm{n}$ & $\%$ \\
\hline Defisit Berat & 52 & 43,3 & 69 & 57,5 \\
\hline Defisit Sedang & 17 & 14,2 & 9 & 7,5 \\
\hline Defisit Ringan & 12 & 10,0 & 9 & 7,5 \\
\hline Baik & 39 & 32,5 & 33 & 27,5 \\
\hline Rata-rata \pm SD (persen AKG) & \multicolumn{2}{|c|}{$90,3 \pm 62,9$} & \multicolumn{2}{|c|}{$76,8 \pm 45,1$} \\
\hline
\end{tabular}

Tabel 3. Tingkat ketahanan pangan rumah tangga

\begin{tabular}{lcccccc}
\hline \multirow{2}{*}{ Kategori Ketahanan Pangan } & \multicolumn{2}{c}{ Medan Kota } & \multicolumn{2}{c}{ Medan Denai } & \multicolumn{2}{c}{ Total } \\
\cline { 2 - 7 } & $\mathrm{n}$ & $\%$ & $\mathrm{n}$ & $\%$ & $\mathrm{n}$ & $\%$ \\
\hline Tidak Tahan Pangan $(<90 \%)$ & 44 & 73,3 & 37 & 61,7 & 81 & 67,5 \\
Tahan Pangan $(\geq 90 \%)$ & 16 & 26,7 & 23 & 38,3 & 39 & 32,5 \\
\hline Total & 60 & 100 & 60 & 100 & 120 & 100 \\
\hline
\end{tabular}

Berdasarkan data pada tabel 2, mengdeskripsikan bahwa rata-rata konsumsi energi perkapita perhari rumah tangga sampel cukup baik yaitu 90,3 \% dari AKG (1994 kkal), berbeda halnya dengan konsumsi protein, dimana rata-rata konsumsi protein pada sampel penelitian masih dikategorikan belum cukup baik dengan persentase 76,8\% dari AKG (51 gram). Mayoritas rumah tangga sampel tergolong dalam kondisi defisit berat yaitu energi $(43,3 \%)$ maupun protein yaitu sebesar 57,5\% (FAO, 2012).

Menurut Depkes RI tingkat kecukupan energi dan protein dikategorikan menjadi 4 kelompok yang terdiri $<70 \%$ (defisit berat), 7080\% (defisit sedang), 80-89\% (defisit ringan) dan $\geq 90 \%$ atau katagori Baik (Hardinsyah et al., 2012a). Tingkat kecukupan energi mayoritas rumah tangga sampel penelitian tergolong kedalam kategori defisit berat $(43,3 \%)$. Hal ini akan berpengaruh nyata terhadap tingkat ketahanan pangan rumah tangga sampel penelitian. Data mengenai tingkat ketahanan pangan rumah tangga sampel dapat dilihat pada tabel 3, yang dapat diketahui bahwa mayoritas rumah tangga sampel tergolong dalam rumah tangga tidak tahan pangan dengan kisaran persentase $67,5 \%$. Berdasarkan penelitian yang dilakukan, Susanti et al. (2015) yang menyatakan bahwa rumah tangga yang tergolong ke dalam rumah tangga rawan pangan adalah rumah tangga yang tidak dapat memenuhi konsumsi rumah tangganya dikarenakan tidak mencukupinya kebutuhan rumah tangga dalam memenuhi kebutuhan pangan

\footnotetext{
Hubungan Karakteristik Rumah Tangga dengan Ketahanan Pangan Rumah Tangga Untuk mengetahui hubungan yang berpengaruh terhadap kondisi tidak tahan pangan pada rumah tangga sampel dapat dilihat hubungan-hubungan variabel rumah tangga dengan ketahanan pangan pada Tabel 4 dibawah ini.
} 
Tabel 4 mengemukakan mayoritas umur kepala rumah tangga sampel penelitian yang terdiri dari dua kecamatan termasuk dalam kelompok dewasa madya (40-59 tahun) dengan persentase 52,5\%. Berdasarkan usia sampel, umur kepala rumah tangga masih tergolong kedalam usia produktif, hal ini sesuai dengan penelitian yang dilakukan Susanti et al. (2015) yang menyatakan bahwa umur karakteristik kepala rumah tangga pada penelitian tergolong dalam usia yang masih produktif bekerja dengan rentang usia berkisar 20-59 tahun. Berdasarkan hasil uji korelasi Pearson menunjukkan bahwa tidak terdapat hubungan yang signifikan ( $\mathrm{p}>$ 0,05 ) antara umur kepala rumah tangga dengan ketahanan pangan rumah tangga di Kota Medan.

Tabel 4. Hubungan pengaruh karakteristik rumah tangga dengan ketahanan pangan

\begin{tabular}{|c|c|c|c|c|c|c|c|}
\hline \multirow[t]{3}{*}{ Variabel } & \multicolumn{4}{|c|}{ Ketahanan pangan } & \multicolumn{2}{|c|}{ Total } & \multirow[t]{2}{*}{ Nilai p } \\
\hline & \multicolumn{2}{|c|}{ Tidak tahan pangan } & \multicolumn{2}{|c|}{ Tahan pangan } & \multirow[b]{2}{*}{$\mathrm{n}$} & \multirow[b]{2}{*}{$\%$} & \\
\hline & $\mathrm{n}$ & $\%$ & $\mathrm{n}$ & $\%$ & & & \\
\hline \multicolumn{8}{|l|}{ Umur KRT } \\
\hline$\geq 60$ tahun & 8 & 9,9 & 3 & 7,7 & 11 & 9,2 & \multirow{3}{*}{0,479} \\
\hline 40-59 tahun & 43 & 53,1 & 20 & 51,3 & 63 & 52,5 & \\
\hline 18-39 tahun & 30 & 37 & 16 & 41 & 46 & 38,3 & \\
\hline \multicolumn{8}{|l|}{ Ukuran Rumah Tangga } \\
\hline > 4 orang & 66 & 81,5 & 32 & 82,1 & 98 & 81,7 & \multirow{2}{*}{0,192} \\
\hline$\leq 4$ orang & 15 & 18,5 & 7 & 17,9 & 22 & 18,3 & \\
\hline \multicolumn{8}{|l|}{ Pengeluaran per bulan } \\
\hline Di bawah GK: <Rp. 234.712,- & 61 & 75,3 & 9 & 23,1 & 70 & 58,3 & \multirow{3}{*}{0,000} \\
\hline Di atas GK : > 234.712,- & 20 & 24,7 & 30 & 76,9 & 50 & 41,7 & \\
\hline \multicolumn{7}{|l|}{ Tingkat Pendidikan } & \\
\hline Tidak sekolah & 5 & 6,2 & 1 & 2,6 & 6 & 5 & \\
\hline SD & 38 & 46,9 & 17 & 43,6 & 55 & 45,8 & \multirow{4}{*}{0,588} \\
\hline SMP & 14 & 17,3 & 9 & 23,1 & 23 & 19,2 & \\
\hline SMA & 21 & 25,9 & 12 & 30,8 & 33 & 27,5 & \\
\hline PT & 3 & 3,7 & 0 & 0 & 3 & 2,5 & \\
\hline Total & 81 & 100 & 39 & 100 & 120 & 100 & \\
\hline
\end{tabular}

Mayoritas ukuran rumah tangga sampel tergolong dalam ukuran rumah tangga besar $(>4$ orang). Berdasarkar hasil analisis korelasi Pearson didapatkan hasil bahwa tidak adanya hubungan signifikan ( $\mathrm{p}>0,05)$ antara umur kepala rumah tangga dengan ketahanan pangan rumah tangga di Kota Medan. Hal ini sejalan dengan penelitian yang dilakukan oleh Amine tahun 2016, dimana hasil penelitiannya menyebutkan tidak terdapat hubungan yang bermakna antara jumlah anggota rumah tangga dengan keragaman yang terjadi di lingkup masyarakat yang ada dipedesaan (Amine, 2016). Menurut penelitian yang dilakukan oleh Hardinsyah, et al yang menjelaskan terdapat berbagai macam model analisis yang umum dilakukan untuk mengetahui determinan tingkat konsumsi pangan pada rumah tangga diantaranya adalah ukuran rumah tangga, pendapatan atau pengeluaran dan harga, dengan semakin besarnya ukuran rumah tangga akan mengakibatkan pengaruh terhadap kurangnya pemilihan bahan makanan yang beragam yang mengakibatkan kurangnya konsumsi pangan pada setiap anggota rumah tangga. Hal ini akan berdampak juga terhadap menurunnya kualitas gizi anggota rumah tangga jika dibandingkan dengan rumah tangga yang berukuran kecil (Hardinsyah et al., 2012a).

Faktor yang berperan sebagai faktor yang memepengaruhi keragaman konsumsi pangan di Indonesia, salah satunya adalah ukuran rumah tangga. Dengan semakin bervariasinya jumlah anggota dalam keluarga/rumah tangga akan berhubungan langsung dengan semakin beragamnya ketersediaan pangan yang dapat dikonsumsi oleh keluarga/rumah tangga tersebut (Hardinsyah et al., 2012a).

Ketahanan pangan dapat dilihat dari persentase pengeluaran yang dikeluarkan oleh 
sebuah rumah tangga, dikarenakan pengeluaran rumah tangga dapat dijadikan tolak ukur untuk mengetahui status ketahanan pangan di suatu rumah tangga. Pengeluaran total perkapita perbulan pada sampel penelitian ini memiliki pengeluaran yang rendah ( $<$ Rp.234.712,-) sedangkan sisanya sebanyak $41,7 \%$ memiliki tingkat pengeluaran yang tinggi.( $\geq$ Rp.234.712,-). Hasil analisis korelasi Pearson dan Rank Spearman menunjukkan terdapat hubungan signifikan antara pengeluaran rumah tangga yang dalam hal ini adalah pengeluaran perkapita perbulan rumah tangga dengan tingkat ketahanan pangan rumah tangga $(\mathrm{p}<0,05)$, Hal ini dapat menjelaskan bahwa dengan semakin besarnya pengeluaran rumah tangga dapat meningkatkan status ketahanan pangan pada rumah tangga sampel. Berdasarkan hal ini, maka pengeluaran rumah tangga mempunyai hubungan langsung dengan dengan ketahanan pangan rumah tangga sampel.

Hal ini sejalan dengan penelitian yang dilakukan oleh Prasmatiwi et al. (2012) yang menyatakan bahwa alokasi pengeluaran rumah tangga berhubungan langsung dengan status ketahanan pangan rumah tangga. Hasil penelitian menjelaskan bahwa rumah tangga yang alokasi pengeluaran pangannya lebih tinggi jika dibandingkan dengan pengeluaran non pangan, dapat digolongkan ke dalam rumah tangga yang tidak tahan pangan karena mayoritas pemenuhan kebutuhan pangannya hanya memenuhi aspek kuantitas jumlah pemenuhan energi saja, akan tetapi kualitas kecukupan gizi belum terpenuhi maksimal.

Hasil penelitian yang dilakukan pada sampel penelitian menunjukkan bahwa sebagian besar berada dalam kondisi yang tidak tahan pangan $(75,3 \%)$ dengan pengeluaran perkapita perbulan berada dibawah Garis Kemiskina atau GK (< Rp. 234.712), pengeluaran rumah tangga yang rendah ini akan berdampak negatif terhadap status ketahanan pangan rumah tangga sampel.

Data pada tabel 4 menginfokan bahwa tingkat pendidikan rata-rata yang ditempuh oleh kepala rumah tangga baik di rumah tangga tahan pangan maupun rumah tangga yang tidak tahan pangan adalah didominasi oleh Sekolah Dasar (SD) dengan persentase sebesar 45,8\%. Hasil analisisi uji korelasi Rank Spearman menunjukkan bahwa tidak terdapat hubungan yang berpengaruh nyata antara tingkat pendidikan dengan ketahanan pangan rumah tangga sampel $(p>0,05)$. Berdasarkan hasil analisis, diduga faktor yang menjadi penyebab adalah kemungkinan dalam hal pemilihan pangan untuk alokasi anggota rumah tangga, tidak ditentukan berdasarkan tingkat pendidikan kepala rumah tangga melainkan didasarkan kebiasaan dan budaya makan yang sudah diadaptasi oleh karakteristik rumah tangga sampel secara lama.

Hasil Penelitian ini juga sejalan dengan penelitian yang dilakukan oleh Jayarni \& Sumarmi (2018), dimana berdasarkan uji statistik yang telah dilakukan didapatkan bahwa tidak terdapat hubungan yang signifikan antara pendidikan terakhir ibu dengan status gizi balita, dimana mayoritas pendidikan ibu balita tergolong rendah, akan tetapi status gizi balitanya dalam keadaan normal. Status sosial ekonomi salah satunya digambarkan oleh tingkat pendidikan. Rendahnya pendidikan orang tua, dalam hal ini ibu, dapat berimplikasi terhadap masalah status gizi anak. Pemahaman yang baik kemungkinan besar akan menimbulkan sifat dan sikap yang baik pula, sehingga kondisi tersebut dapat mencegah terjadinya masalah gizi yang tidak diinginkan.

Penelitian sejenis juga dilakukan oleh Astuti tahun 2010 dimana hasil penelitiannya menjelaskan bahwa tidak terdapat hubungan yang signifikan antara pendidikan ibu dengan status gizi anak prasekolah (Astuti \& Sulistyowati, 2010). Rata-rata konsumsi energi perkapita perhari rumah tangga sampel penelitian tergolong cukup baik dengan persentase 90,3\% dari AKG (1994 kkal), sedangkan untuk rata-rata konsumsi protein masih tergolong belum cukup baik dengan persentase $76,8 \%$ dari AKG (51 gram). Pada hasil penelitian, didapatkan bahwa sebagian besar sampel penelitian tergolong dalam rumah tangga tidak tahan pangan. Pada penelitian ini juga akan melihat pengaruh tingkat konsumsi energi dan protein terhadap tingkat ketahanan pangan rumah tangga. Hal ini dikarenakan dalam mengukur suatu ketahanan pangan di rumah tangga digunakan alat ukur dalam bentuk tingkat konsumsi pangan. Menurut "teori konsumsi Keynes dalam bukunya yang berjudul The General Theory of Employment, Interest and Money menjelaskan bahwa adanya hubungan antara pendapatan yang diterima saat ini (pendapatan disposabel) dengan konsumsi yang 
dilakukan saat ini juga" (Keynes, 2017). Hal ini juga diperkuat dengan penelitian yang dilakukan oleh Pujoharso, yang menyatakan bahwa pendapatan berhubungan dengan konsumsi pangan yang dilakukan oleh manusia, dimana pendapatan yang telah dimiliki pada waktu tertentu akan mempengaruhi konsumsi pada waktu tersebut. Dengan kata lain apabila pendapatan meningkat sebaliknya konsumsi juga akan mengalami peningkatan (Pujoharso, 2013). Data mengenai tingkat kecukupan energi rumah tangga sampel penelitian menunjukkan hasil bahwa mayoritas rumah tangga sampel penelitian tergolong dalam defisit berat. Menurut Depkes RI (Kemenkes RI, 2013) tingkat kecukupan energi dan protein dikategorikan menjadi 4 kelompok kategori yaitu $<70 \%$ (defisit berat), $70-80 \%$ (defisit sedang), 80-89\% (defisit ringan ) dan $\geq 90 \%$ (Baik). Rumah tangga sampel dalam penelitian ini tergolong kedalam rumah tangga dengan tingkat kecukupan defisit berat $(43,3 \%)$.

Hasil penelitian menunjukkan bahwa pemenuhan zat gizi sampel khususnya energi dan protein belum mencukupi kecukupan yang yang dianjurkan. Hal ini dapat disebabkan karena rumah tangga sampel dalam penelitian ini sebagian besar tergolong dalam rumah tangga miskin, yang dilihat dengan tingkat pengeluaran pangan berada di bawah garis kemiskinan (GK). Hal lain yang juga menyebabkan tingkat kecukupan zat gizi rumah tangga sampel rendah adalah ukuran rumah tangga sampel penelitian tergolong dalam ukuran rumah tangga yang luas (extended family).

Ketahanan pangan menurut Tanziha terbagi menjadi dua aspek yaitu kuantitatif dan aspek kualitatif, untuk mengukur ketahanan pangan secara kualitatif dapat diukur melalui tingkat kelaparan pada rumah tangga yang diukur berdasarkan petunjuk kuesioner yang diberikan kepada rumah tangga (Tanziha, 2011). Berbeda halnya dengan mengukur ketahanan pangan secara kuantitatif, untuk analisis kuantitatif, ketahanan pangan diukur berdasarkan tingkat kecukupan energi rumah tangga/keluarga dengan tingkatan kategori yang terdiri dari: jika tingkat kecukupan energinya < 90,0\% (tidak tahan pangan), sedangkan jika tingkat kecukupan energinya $\geq 90,0 \%$ (tahan pangan) (Hardinsyah et al., 2012b).

Data tingkat ketahanan pangan rumah tangga sampel menunjukkan bahwa, bahwa sebagian besar rumah tergolong dalam rumah tangga tidak tahan pangan, hal tersebut mengidentifikasikan perlu dilakukannya analisis pengaruh faktor-faktor yang mempengaruhi ketahanan pangan rumah tangga sampel. Berdasarkan penelitian yang dilakukan oleh Hapsari \& Rudiarto (2017), yang menyatakan untuk melihat dan mengetahui berbagai macam faktor yang dapat mempengaruhi tingkat ketahanan pangan rumah tangga dan masalah kelaparan pada rumah tangga dapat dilakukan analisis jalur faktor berdasarkan intrumen indikator-indikator pengaruh, dimana didapatkan empat kelompok indikator faktor yang mempengaruhi ketahanan pangan yang terdiri dari faktor ketersediaan pangan, social ekonomi, fisik alam dan dampak kesehatan.

Penelitian tersebut sejalan dengan dengan penelitian yang dilakukan pada sampel penelitian ini, di mana faktor yang dominan mempengaruhi ketidaktahanan pangan dalam rumah tangga adala faktor ekonomi yaitu pengeluaran perkapita/perbulan pada rumah tangga. Hasil analisis regresi berganda dapat dilihat pada Tabel 5.

Tabel 5. Hasil analisis regresi berganda

\begin{tabular}{|c|c|c|c|c|c|c|c|}
\hline \multirow{2}{*}{\multicolumn{2}{|c|}{ Model }} & \multicolumn{2}{|c|}{$\begin{array}{c}\text { Unstandardized } \\
\text { Coefficients }\end{array}$} & \multirow{2}{*}{$\begin{array}{c}\text { Standardized } \\
\text { Coefficients } \\
\text { Beta }\end{array}$} & \multirow[b]{2}{*}{$\mathrm{t}$} & \multicolumn{2}{|c|}{$\begin{array}{c}\text { Collinearity } \\
\text { Statistics }\end{array}$} \\
\hline & & $\mathrm{B}$ & Std. Error & & & Tolerance & VIF \\
\hline 1 & (Constant) & 0.884 & 0.243 & & 3.645 & & \\
\hline & Umur_KRT & -0.073 & 0.064 & -0.099 & -1.152 & 0.915 & 1.093 \\
\hline & Ukuran_RT & -0.003 & 0.100 & -0.002 & -0.028 & 0.962 & 1.039 \\
\hline & Pendidikan_KRT & -0.022 & 0.040 & -0.048 & -0.568 & 0.940 & 1.064 \\
\hline & Pengeluaran_RT & 0.434 & 0.077 & 0.463 & 5.614 & 0.993 & 1.007 \\
\hline
\end{tabular}

Hasil analisis uji regresi pada tabel 5 menunjukkan bahwa faktor yang berpengaruh nyata terhadap ketahanan pangan rumah tangga sampel penelitian adalah pengeluaran rumah tangga dengan hasil perhitungan sebagai berikut ini: 
$\mathrm{Y}=0,884+0,434 \mathrm{x}$

Setiap koefisien regresi $\beta \mathrm{x}$ (pengeluaran rumah tanggga/kap/bulan) sebesar 0,434 menyatakan bahwa setiap peningkatan 1 tingkat pengeluaran perkapita perbulan di rumah tangga sampel akan meningkatkan ketahanan rumah tangga sampel sebesar 0,434 poin. Analisis regresi dilakukan pada semua variabel yang diduga memberi pengaruh terhadap ketahanan pangan rumah tangga sampel, dan hasilnya adalah pengeluaran rumah tangga yang berpengaruh nyata terhadap ketahanan pangan rumah tangga sampel. Berdasarkan hasil penelitian yang dilakukan terdapat pengaruh langsung pengeluaran terhadap ketahanan pangan rumah tangga, hal ini diperkuat dengan penelitian yang dilakukan oleh Agbola (2014), yang menyatakan bahwa beberapa faktor yang memiliki hubungan dengan ketahanan pangan diantaranya adalah pengeluaran dan total pendapatan rumah tangga, pendapatan dan pengeluaran tersebut juga akan berimplikasi langsung terhadap status ketahanan pangan rumah tangga petani berlahan kecil di Nigeria, Afrika. Dengan kata lain, tidak hanya pendapatan rumah tangga saja yang dapat dijadikan indikator kesejahteraan rumah tangga, akan tetapi pengeluaran rumah tangga juga dapat dijadikan indikator kesejahteraan rumah tangga sehingga mempengaruhi tingkat ketahanan pangan suatu rumah tangga (Firdaus et al., 2015).

\section{Kesimpulan}

Sebagian besar rumah tangga termasuk dalam rumah tangga tidak tahan pangan. Faktor penting yang berpengaruh nyata terhadap ketahanan pangan rumah tangga di Kota Medan adalah pengeluaran rumah tangga. Rumah tangga dengan kontribusi pengeluaran yang tinggi dapat memberikan pengaruh dan kontribusi langsung terhadap status ketahanan pangan rumah tangga.

Saran, yang dapat diberikan adalah diharapkan adanya strategi dan inovasi baru yang diberikan oleh pemerintah daerah, kota dan pusat dalam bentuk pemberdayaan rumah tangga yang dikelola secara terstruktur dan merata pada lapisan masyarakat untuk mengatasi permasalahan ketahanan pangan rumah tangga/keluarga.

\section{Daftar Rujukan}

Agbola, P. 0. (2014). Factors influencing food insecurity among small farmers in Nigeria. African Journal of Agricultural Research, 9(27), 2104-2110. https://doi.org/10.5897/ajar09.710

Amine, B. M. (2016). Determinants of on-Farm Diversification Among Rural Households: Empirical Evidence From Northern Algeria. International Journal of Food and Agricultural Economics, 4(2), 87-99. https://doi.org/10.22004/ag.econ.234912

Arlius, A. (2017). Hubungan Ketahanan Pangan Keluarga Dengan Status Gizi Balita (Studi Di Desa Palasari Dan Puskesmas Kecamatan Legok). Jurnal Ketahanan Nasional, 23(3), 359-375.

Astuti, F. D., \& Sulistyowati, T. F. (2010). Pendapatan Keluarga Dengan Status Gizi Anak. Jurnal Kesehatan Masyarakat, 7(1), 15-20.

Biro Pusat Statistik. (2018). Keadaan Ketenagakerjaan Indonesia. In Berita Resmi Statistik.

BNP2TKI. (2019). Laporan kinerja badan ketahanan pangan tahun 2018. In Badan Ketahan

Pangan. https://doi.org/10.3406/arch.1977.1322

BPS. (2019). Provinsi Sumatera Selatan Dalam Angka 2019. In Badan Pusat Statistik Provinsi Sumatera Selatan.

Conceição, P., Levine, S., Lipton, M., \& WarrenRodríguez, A. (2016). Toward a food secure future: Ensuring food security for sustainable human development in SubSaharan Africa. Journal Food Policy, 60, 1-9. https://doi.org/10.1016/j.foodpol.2016.02. 003

Damayanti, V. L., \& Khoirudin, R. (2016). Analisis Faktor - Faktor Yang Mempengaruhi Ketahanan Pangan Rumah Tangga Petani (Studi Kasus: Desa Timbulharjo, Sewon, Bantul). Jurnal Ekonomi \& Studi Pembangunan, 17(2), 89-96. https://doi.org/10.18196/jesp.17.2.3735

Emy, R. (2012). Aspek Distribusi Pada Ketahanan Pangan Masyarakat Di Kabupaten Tapin. Jurnal Agribisnis, 2(3), 241-251.

FAO. (2012). The State of Food Insecurity in the World 2011 Key messages. In Organization. https://doi.org/10.1519/JSC.0b013e3181b $8666 \mathrm{e}$

Firdaus, M., Apriliani, T., \& Wijaya, R. A. (2015). 
Pengeluaran rumah tangga nelayan dan kaitannya dengan kemiskinan: Kasus di Desa Ketapang Barat, Kabupaten Sampang, Jawa Timur. Jurnal Sosial Ekonomi Kelautan Dan Perikanan, 8(1), 49. https://doi.org/10.15578/jsekp.v8i1.1195

Hapsari, N. I., \& Rudiarto, I. (2017). Faktor-Faktor yang Mempengaruhi Kerawanan dan Ketahanan Pangan dan Implikasi Kebijakannya di Kabupaten Rembang. Jurnal Wilayah Dan Lingkungan, 5(2), 125. https://doi.org/10.14710/jwl.5.2.125-140

Hardinsyah, Riyadi, H., \& Napitupulu, V. (2012a). Kecukupan energi, protein, lemak dan karbohidrat. Departemen Gizi FK UI.

Hardinsyah, Riyadi, H., \& Napitupulu, V. (2012b). Kecukupan energi, protein, lemak dan karbohidrat. In Departemen Gizi FK UI (pp. 1-26). Fakultas Kedokteran, Universitas Indonesia.

Jayarni, D. E., \& Sumarmi, S. (2018). Hubungan Ketahanan Pangan dan Karakteristik Keluarga dengan Status Gizi Balita Usia 2 - 5 Tahun ( Studi di Wilayah Kerja Puskesmas Wonokusumo Kota Surabaya ) Relationship between Food Security, Family Characteristics with Nutritional Status of Children a. Amerta Nutrition, 2(1), 44-51. https://doi.org/10.20473/amnt.v2.i1.2018. 44-51

Kamoo, G., Malaya, U., Norani, M., \& Salleh, M. (2017). Pengaruh struktur keluarga dan stail keibubapaan terhadap pencapaian akademik murid India di sekolah menengah rendah. JuKu: Jurnal Kurikulum \& Pengajaran Asia Pasifik -Januari, 2(1), 4453.

Kemenkes RI. (2013). Angka Kecukupan Gizi (AKG) 2013. In Balitbangkes RI. Badan Penelitian dan Pengembangan Kesehatan,
Kemenkes

RI. https://doi.org/10.1007/BF03077564

Keynes, J. M. (2017). The General Theory of Employment, Interest and Money. In Modern Economic Classics-Evaluations Through Time. https://doi.org/10.4324/978131527054813

Mekonnen, D. A., \& Gerber, N. (2017). Aspirations and food security in rural Ethiopia. Journal Food Security, 9(2), 371-385. https://doi.org/10.1007/s12571-0170654-6

Musindar, I., \& Arhim, M. (2018). Ketahahan pangan rumah tangga pembuat tortila di Kota Palopo. Jurnal Perbal, 6(2), 43-52.

Prasmatiwi, F. E., Listiana, I., \& Rosanti, N. (2012). Pengaruh Intensifikasi Pertanian Terhadap Ketahanan Pangan Rumah Tangga Petani Padi di Lampung Tengah. Prosiding SNSMAIP III, 162-167.

Pujoharso, C. (2013). Aplikasi teori konsumsi keynes terhadap pola konsumsi makanan masyarakat Indonesia. Jurnal Ilmiah Mahasiswa FEB, 1(2), 10-16.

Sumardilah, D. S., \& Rahmadi, A. (2015). Faktorfaktor yang berhubungan dengan ketahanan pangan rumah tangga. Jurnal Keperawatan, 11(2), 270-278.

Susanti, E., Fauzi, T., \& Taufiqurrahman. (2015). Analisis Ketahanan Pangan Rumah Tangga Petani di Desa Ulee Lhat Kecamatan Montasik Kabupaten Aceh Besar. Bisnis Tani, 1(1), 11-23.

Tanziha, I. (2011). Model Pemberdayaan Petani Menuju Ketahanan Pangan Keluarga. Jurnal Gizi Dan Pangan, 6(1), 90-99. https://doi.org/10.25182/jgp.2011.6.1.9099 